\title{
MAPS OF ROMAN DACIA. I. THE MAP OF PETRUS KAERIUS (1571-1646)
}

Florin Fodorean

Babeş-Bolyai University Cluj-Napoca Faculty of History and Philosophy Department of Ancient History and Archaeology E-mail: fodorean_f@yahoo.com

DOI: http://dx.doi.org/10.14795/j.v1i1.14

ISSN 2360 - 266X

ISSN-L 2360 - 266X

\begin{abstract}
In the following, we would like to present and describe a very interesting map, engraved in the XVII ${ }^{\text {th }}$ or at the end of the XVI ${ }^{\text {th }}$ century by a famous Dutch cartographer, engraver, and publisher: Pieter van der Keere (Petrus Kaerius). Born in Ghent in 1571, Van der Keere (1571-1646) developed his business in Amsterdam at the end of the XVI ${ }^{\text {th }}$ century. The map described in our article is entitled Vetus Descriptio Daciarum nec non Moesiarum. The document is important for the history of cartography because it enable us to identify and comment upon the level of knowledge of Van der Keere about a region not so familiar to him. In fact, the map reflects a medieval version of the map of Ptolemy. This period is connected to the rediscovery of Ptolemy. Besides data from the famous work of the geographer born in Alexandria, Van der Keere included some interesting notations and details which reflect the middle Ages conceptions or geographical features invented in this period.
\end{abstract}

\section{Introduction}

$\mathbf{w}$ e would like to begin, with this article, a series of contributions focused on ancient, medieval and modern maps which depict the territory of the former province of Dacia. ${ }^{1}$ The purpose of this initiative is to bring into the attention of the historians some useful information about the history of cartography and the evolution of the general perception of the regions north of the Danube during the medieval and the modern times. The most important purpose of our studies is to get the study of historical maps as fundamental instruments of archaeological prospection, for the identification, mapping and evaluation of the archaeological patrimony.

Another aim of our approach is to revaluate the cartographic heritage and to understand the importance of maps. Nowadays, the history of cartography

\footnotetext{
${ }^{1}$ Babeş-Bolyai University Cluj-Napoca, Faculty of History and Philosophy, Department of Ancient History and Archaeology, Romania. This study represents a part of my research project, entitled "Cartografierea digitală a siturilor romane din Dacia Porolissensis" ("Digital mapping of the archaeological sites in Dacia Porolissensis'), grant GTC 34034/01.11.2013. This project is implemented as a grant for postdoctoral researchers, financially sustained by the Babeş-Bolyai University Cluj-Napoca in 2013-2014.
} 
today gained academic significance and scholars of humanities or social sciences understood the potential of the maps for their own disciplines. The biggest step forward was, obviously, the great synthesis imagined and then edited by J. B. Harley and David Woodward, History of Cartography. ${ }^{2}$ Before the initiation of their innovative and challenging project, other scholars focused their efforts to promote and encourage the study of historical maps. In the last century, the contributions of Leo Bagrow ${ }^{3}$ were essential for the research of the history of cartography, not only because he published a synthesis about the history of the map, ${ }^{4}$ but mainly because he succeeded to create the first international journal for the history of cartography, i.e. Imago Mundi. ${ }^{5}$ Bagrow's legacy has encouraged new generations of scholars across humanities or social science to continue to study the maps and to promote them as products of great cultural significance for many disciplines, not only for geography. ${ }^{6}$

\section{The map of Dacia by Pieter van den Keere (Peter Kaerius, $1571-$ c.1646) ${ }^{7}$}

Pieter van der Keere was born in Ghent in 1571. After a period spent in England, Van der Keere returned to Netherlands, starting a business in Amsterdam, working in close associations with two famous map-houses: Hondius and Jansson. ${ }^{8}$ During his activity, he prodeced maps for atlases or maps of differents regions, including the Netherlands, England, and other regions of Europe. He was also involved in producing large city panoramas, such as those of Utrecht, Cologne, Amsterdam, Paris, Constantinople, Danzig, Hamburg. ${ }^{9}$ He also produced maps of the world and its continents. Van der Keere was part of the golden age of Dutch cartography.

\section{1. The title of the map of Dacia}

The map has no scale. The title of the map is "Vetus Descriptio Daciarum nec non Moesiarum". In the title one can find an interesting reference, regarding the unknown location of several settlements from Moesia and Dacia ("Urbes incognitae positionis huc referenda sunt"). This title is followed by a list of settlements from Moesia I, Moesia II and Dacia.

\section{2. Mathematical elements of the map: latitude and longitude}

There is also an attempt to indicate the values of the geographical coordinates, which are written on the edges

\footnotetext{
${ }^{2}$ Online: http://www.press.uchicago.edu/books/HOC/index.html. See also HARLEY 1987, 1-42 (chapter 1: The Map and the Development of the History of Cartography).

${ }^{3}$ He was born Lev Semenovich Bagrow. Leo Bagrow (1881-9 August 1957) was one of the most important cartographers of the last century.

${ }^{4}$ BAGROW 1951; BAGROW 1964.

Online: http://www.tandfonline.com/toc/rimu20/current\#. Uxcmb85 1A-. Also SKELTON 1959, 4-12.

${ }^{6}$ HARVEY 1980; JANNI 1984; DILKE 1985; WOODWARD 2000, 23-31; EDNEY 2005, 14-29.

${ }^{7}$ Online: http://www.raremaps.com/gallery/enlarge/29803lh.

${ }^{8}$ KEUNING 1960, 66.

${ }^{9}$ KEUNING 1960, 69.
}

of the map. The values of the latitude are accurate. We should have in mind that latitudes were known in antiquity, because of the essential contributions of the Greek geographers, especially Eratosthenes. ${ }^{10}$ Instead, the values of the longitude are not correctly represented. We have identified the same mistake perpetuated since the Roman period. In his Geographike Hyphegesis, Ptolemy indicated these values starting from a line positioned almost $23^{\circ}$ west of the current meridian of $0^{\circ}$, which is the Greenwich meridian. ${ }^{11}$ If we look carefully, we observe that the center of the map is marked with the value of $47^{\circ}$, which should correspond with the value of $47^{\circ}-23^{\circ}=24^{\circ}$, the value of the central meridian which crosses nowadays from north to south the territory of Romania.

The values of the meridians are high. The territory of modern Romania is located between the meridians of $20^{\circ} 15^{\prime} \mathrm{E}$ and $29^{\circ} 41^{\prime} \mathrm{E}$ and the parallels of $43^{\circ} 37^{\prime} \mathrm{N}$ and $48^{\circ} 15^{\prime} \mathrm{N} .{ }^{12}$ The values of the meridians are measured starting from the Ferro meridian (Canare Islands). This meridian was until 1884 used as the null meridian in the German and AustroHungarian cartography. It was then replaced by the meridian of Paris and then with that from Greenwich. ${ }^{13}$

We should also notice that in the upper part of the map, the values of the longitude start with $39^{\circ}$, while in the lower part the values start at $41^{\circ}$.

\section{3. Data about the surrounding areas}

The cartographer recorded the surrounding areas around Dacia. In the north-west Germaniae Pars is marked. In the south-western area Pannoniae Pars is recorded. In the southern part Pars Thraciae is mentioned. In the north and the north-eastern part Sarmatiae Europeae Pars is recorded, together with the mentioning of Bastarnae and Roxolani. In the eastern part the Black Sea is marked as Ponti Euxini Sarmatici, sive Scythici Pars.

\section{4. The content of the map: the hydrographic network}

The network of rivers is organized around the main axis: the Danube. The river is named Danubius flu. qui et Hister. At the bottom of the map there is another mentioning: Ister flu. qui et Danubius. Five Danube branches are also represented. Besides the Danube, other rivers are also mapped. The majority are northern tributaries of the Danube. In Pannonia the following rivers are represented: Granua flu., Urpanus flu., Dravus flu. (the Drava River) and Savus flu (the Sava River). Another important river in Dacia, represented with numerous branches in the map, is Tibiscus $f l$ (Timiş). Five branches of the river are drawn in the northern part of Dacia, close to the Carpates mons. The river is also described in detail, as Tibiscus Ptol. Patisius Plinio Tisianus

\footnotetext{
${ }^{10}$ AUJAC 1987, 153-157.

11 For Ptolemy: DILKE 1987, 177-200; BERGGREN, JONES 2000; STÜCKELBERGER, MITTENHUBER 2009; ISAKSEN 2011, 254-260.

12 That is why Roman Dacia is represented in Tabula Imperii Romani in the sections L 34, 35.

13 The meridian took its name from the most western island from the Canaries, El Hierro. Starting from Antiquity, this was used as the zero meridian. Ptolemy measured the longitudes from it towards East. It was used during the whole medieval and modern period, since it offered only positive longitudes for the territories of Europe.
} 
Jornandi. The tributaries of Tibiscus are also represented. One is Chrysius flu. Iornandi qui Cusus Taciti (the Criş River). The other two are Aqua nigra flu. and Scarniunga flu.

Another tributary of the Danube is Rhabon qui et Marisus flu. Rhabon (currently the Jiu River) has another tributary, namely Sargetia flu. in quo Decebalus rex thesauris occultaverat. Another river which flows into the Danube is Aluta flu. (the Olt River), represented in the map crossing the entire Dacian province. The following rivers, drawn in the eastern part of the map, are almost parallel with Alutus. All of them are represented as northern tributaries of the Danube. These rivers are: Tiarantus flu., Ararus flu., Naparis flu., Ordessus flu. The river Prut is also mapped and it is presented as Hierasus flu. Ptol. Gerasus Ammianus. The easternmost river represented in the map is Tyras flu.

As one can observe from our description, some of the main rivers of Dacia are mapped, but the geographical features and the lines of these rivers are far away from the geographical realities. South of the Danube, in Moesia, the following rivers are mapped: Mosehius flu., Timachus flu., Pingus flu., Utus flu., Margis flu., Ciabrus et Ceius flu., Eseamus flu., Zyras flu. and Naxius Flu. We should notice the interesting representation of the Ciabrus River, which touches the line of the Haemus mountains, in order to indicate the separation between the two provinces of Moesia, named in the map Moesia I. sive Superior and Moesia II. Vel Inferior.

\section{5. The content of the map: the settlements}

The map depicts almost all the settlement in Roman Dacia listed by Ptolemy in his geographical work. The settlements mapped are (from left to right, from north to south): 1. Ruconium; 2. Saline; 3. Docirava; 4. Porolissum; 5. Arcobadara; 6. Triphulum; 7. Napuce; 8. Pretoria Augusta; 9. Sandava; 10. Petrodava; 11. Patrovissa; 12. Marcodava; 13. Utidava; 14. Angustia; 15. Patruissa; 16. Cumidava; 17. Alba Iulia, quae Apulum; 18. Slotna, ubi Aurarie (Zlatna); 19. Tiriscum, quod Taros; 20. Ziridava; 21. Transalba; 22. Zurobara; 23. Singidava; 24. Ulpia Traiana col. Aug. Zarmizogethusa; 25. Tapae.

In Dacia, south of the drawing representing the Carpates mons, between these mountains and the Danube, the following cities are mapped: 26. Lizisis (ground form Aizis); 27. Zeugma; 28. Druphegis (Drobeta); 29. Genadium; 30. Romulianum ubi Galerij Imp. Sepultura sic dictum a Romula huius matre (Romula); 31. Dierna; 32. Galtis; 33. Transdiernum; 34. Tibiscum; 35. Zarnes; 36. Acmonia; 37. Phrateria; 38. Argidava; 39. Amutrium; 40. Arcina; 41. Pinum; 42. Zermizirga (Germisara); 43. Hydata sive Aque (Aquae); 44. Tiasum; 45. Sornum; 46. Tigra; 47. Marisca; 48. Ramidava; 49. Pirum; 50. Nentidava; 51. Poloda; 52. Zusidava; 53. Maetonium; 54. Clepidiana; 55. Patridava; 56. Carsidava; 57. Zargidava; 58. Tamasidava; 59. Piroboridava. Several cities from Dobroudja are also mapped: 1 . Troesmis; 2. Arubium; 3. Dimigutia (ground form Dinogetia).

In Pannonia, along the course of the Danube River, the map records the following settlements: 1 . Transacincum; 2. Lusonium; 3. Partiscum; 4. Ad Statuas colossas; 5.
Altinum; 6. Varonianum; 7. Singidonum; 8. Teutaburgum; 9. Cornacum; 10. Onagrinum; 11. Pistrensis villa; 12. Rhittium.

Analyzing the geographical repartition of these settlements, one can easily observe that the author of the map, Petrus Kaerius, had no clue about the topography of Dacia. It is normal. The real, accurate maps of the province will be published only at the beginning of the $\mathrm{XX}^{\text {th }}$ century. Obviously, we should not judge so harshly the cartographer. The distribution of the cities within the map reflects, almost identically, the map of Dacia drawn by Ptolemy. This map was known during the middle Ages, when Ptolemy was rediscovered. ${ }^{14}$ During that period, numerous maps based on the information from Ptolemy were drawn. Turning back now to the cities, we observe, for example, that Saline (Salinae) is located in the northern part of the province, which is, obviously, not at all correct. In the southern part of the province, Tibiscum is mapped close to the course of the Danube River, which is, again, incorrect. Druphegis (Drobeta) instead is mapped along the course of the Rhabon $f l u$., which is, again, another mistake.

\section{6. The content: the provinces}

Three regions of Dacia are indicated in the map of Pieter van der Keere. In the center of the map Dacia Mediterranea quae Gepidia is represented. This area is surrounded by the Carpates mons. Represented in this manner, the central part of the map reminds of Transylvania. In the western and the south-western part of Dacia Mediterranea another area is mentioned as Dacia Ripensis. In the mind of the cartographer, this region included the western part of Transylvania, Banat and the western part of Oltenia. The third region is Dacia Alpestris. It includes, roughly, the territory of today's eastern Oltenia, Muntenia and Moldavia. The name of Dacia Alpestris is a medieval creation. It is mentioned starting with the XVII ${ }^{\text {th }}$ and the XVIII ${ }^{\text {th }}$ century. For example, Iosef Christof Becman (1641-1717) was convinced that Walachia and Moldavia formed together Dacia Alpestris. There are also other similar cases, when medieval geographers or historians have used this denomination. ${ }^{15}$

\section{7. The content: the vignettes, the}

names of the tribes and other data

As in the Geography of Ptolemy, the map of Van der Keere also contains the names of the tribes and the districts in Roman Dacia. These are: Anarti, Teurisci, Cistoboci, Biephi, Ciagesi, Piephigi, Predavesij, Ratacensij, Cacoensij, Buridiensij, Cotensij, Albocensij, Potulatensij, Saldensij, Sinsij, Taiphali, Theruingi, Burrhi. Ptolemy mentions 15 names of districts in Roman Dacia: Anarti, Teurisci, Coestoboci, Biephi, Ciasigi, Piephigi, Predavenses, Rhatacenses, Caucoenses, Buridavenses, Cotenses, Albocenses, Potulatenses, Saldenses and Senses. ${ }^{16}$ In this case, we have observed a certain attention for the mention-

\footnotetext{
${ }^{14}$ DALCHÉ 2007, 285-364. Online: http://www.press.uchicago.edu/books/ HOC/HOC_V3_Pt1/HOC_VOLUME3_Part1_chapter9.pdf.

${ }^{15}$ BĂLAN 1973, 88-89. Online: http://www.muzeulbucovinei.ro/studii_si_ materiale_3/index.html\#/84.

${ }^{16}$ NEMETI 2006, 277.
} 
ing of these names. Almost every city mentioned din Dacia is represented with a small drawing. The importance of Ulpia Traiana is revealed by the size of this drawing, larger comparing to the others.

Two interesting notations in the map should be mentioned. The first one is Tabe accessus ad Daciam. Close to this point, the settlement of Tapae is represented. In fact, the cartographer made several mistakes. He imagined and he represented Tapae along the Olt River. The second notation mentions Bontar, accessus e Moesia in Daciam.

\section{Conclusions}

The map presented in this article reflects the medieval perception about the Dacian territories. The representation is, obviously, as we describe it, a mixture between data from Ptolemy and other toponyms and geographical features created during the medieval period. It is one of the earliest maps depicting the territory of Roman Dacia. The study of such maps will reveal, in the future, a gradual image of how geographical and historical knowledge about certain regions or territories changed and improved.

\section{BIBLIOGRAPHY AND REFERENCES}

AUJAC 1987 G. Aujac, The Growth of an Empirical Cartography in Hellenistic Greece, in J. B. Harley, D. Woodward (eds.), The History of Cartography. Volume one. Cartography in Prehistoric, Ancient and Medieval Europe and the Mediterranean, The University of Chicago Press, Chicago and London, 1987, 148-160.

BAGROW 1951 Leo Bagrow, Die Geschichte der Kartographie, Berlin, Safari Verlag, 1951.

BAGROW 1964 Leo Bagrow, History of Cartography, Cambridge, Harvard University Press, London, 1964.

BĂLAN 1973 T. Bălan, Numele Moldova - O istoriografie a problemei, in Studii și materiale. Istorie 3 (Muzeul Suceava), 1973, 77-112.

BERGGREN, JONES 2000 J. L. Berggren, A. Jones, Ptolemy's Geography. An Anntoated Translation of the Theoretical Chapters, Princeton, Princeton University Press, 2000.

DALCHÉ 2007 P. Gautier Dalché, The Reception of Ptolemy's Geography (End of the Fourteenth to Beginning of the Sixteenth Century), in D. Woodward (ed.), The History of Cartography. Volume three. Cartography in the European Renaissance, Part 1, The University of Chicago Press, Chicago \& London, 2007, 285-364.

DILKE 1985 O. A. W. Dilke, Greek and Roman Maps, London, 1985.

DILKE 1987 O. A. W. Dilke, The Culmination of Greek Cartography in Ptolemy, in B. Harley, D. Woodward (edS.), The History of Cartography. Volume one. Cartography in Prehistoric, Ancient and Medieval Europe and the Mediterranean, The University of Chicago Press, Chicago and London, 177-200.

EDNEY 2005 M. H. Edney, Putting Cartography into the History of Cartography: Arthur H. Robinson, David Woodward, and the Creation of a Discipline, in Cartographic Perspectives 51, 2005, 14-29.

HARLEY 1987 J. B. Harley, The Map and the Development of the History of Cartography, in J. B. Harley, D. Woodward (eds.), The History of Cartography. Volume one. Cartography in Prehistoric, Ancient and Medieval Europe and the Mediterranean, The University of Chicago Press, Chicago and London, 1987, 1-42.
HARVEY 1980 P. D. A. Harvey, The History of Topographical Maps: Symbols, Pictures and Surveys, London, Thames and Hudson, 1980.

ISAKSEN 2011 L. Isaksen, Lines, damned lines and statistics: unearthing structure in Ptolemy's Geographia, in e-Perimetron, vol. 6, no. 4, 2011, 254-260. Online at: http://www.e-perimetron. org/Vol_6_4/Isaksen.pdf.

JANNI 1984 P. Janni, La mappa e il periplo: Cartografia antica e spazio odologico, Università di Macerata, Pubblicazioni della Facoltà di Lettere e Filosofia, 19, Rome, Bretschneider, 1984.

KEUNING 1960 J. Keuning, Pieter van der Keere (Petrus Kaerius), 1571-1646 (?), in Imago Mundi 15, 1960, 66-72.

NEMETI 2006 S. Nemeti, Dacia...in formam provinciae redacta, in E. S. Teodor, O. Țentea (eds.), Dacia Augusti Provincia. Crearea provinciei, Bucharest, 2006, 271-288.

SKELTON 1959 R. A. Skelton, Leo Bagrow: Historian of Cartography and Founder of Imago Mundi, 1881-1957, in Imago Mundi 14, 1959, 4-12.

STÜCKELBERGER, MITTENHUBER 2009

A. Stückelberger, F. Mittenhuber, Ptolemaios. Handbuch der Geographie. Ergänzungsband, Basel, 2009.

WOODWARD 2000 D. Woodward, Origin and History of the History of Cartography, in D. Woodward, C. Delano-Smith, C. D. K. Yee (eds.), Approaches and Challenges in a Worldwide History of Cartography, Barcelona, 2000, 23-31. 